\title{
PROJEKT KONCEPCYJNY GLOBALNEGO SYSTEMU NAWIGACYJNEGO DLA MARSA
}

\begin{abstract}
Współcześnie Mars stał się obiektem bezprecedensowego wyścigu wielu państw w eksploracji planety, której ukoronowaniem ma się stać lądowanie ludzi na powierzchni Czerwonej Planety. Załogowa wyprawa na Marsa będzie wymagać stworzenia globalnego systemu nawigacyjnego planety oraz zapewnienia ciągłej, szerokopasmowej transmisji danych z Ziemią. Współczesna nawigacja sond międzyplanetarnych znajdujących się w dalekiej przestrzeni kosmicznej jest procesem złożonym, czasochłonnym i kosztownym, wymagającym do pracy złożonej infrastruktury naziemnej. Proces nawigacji jest całkowicie nieautonomiczny, sonda nie jest w stanie, wykorzystując aparaturę pokładową, określić swojego położenia przestrzennego w przyjętym układzie odniesienia. W pracy został przedstawiony projekt koncepcyjny dopplerowskiego globalnego systemu nawigacyjnego dla planety Mars, pozwalającego na określenie położenia obiektu na powierzchni planety i w bliskiej przestrzeni w czasie nieprzekraczającym $2 \mathrm{~h}$, oraz systemu łączności, zapewniającego wzajemną łączność pomiędzy sondami / lądownikami i retransmisję danych z powierzchni Marsa na Ziemię.
\end{abstract}

Słowa kluczowe: Mars, system nawigacyjny, transmisja danych

\section{Wprowadzenie}

Mars fascynował i kreował wyobraźnię człowieka od tysiącleci. Starożytni Rzymianie nazwali jego imieniem swego boga wojny, wyobrażając sobie, że jego rdzawo-czerwone zabarwienie powstało z krwi poległych wojowników ${ }^{2}$ [1]. Dotychczasowa eksploracja Marsa prowadzona przez człowieka obejmuje 40 prób wysłania sond międzyplanetarnych w kierunku planety, poczynając od przelotu sondy w pobliżu planety (np. Mariner 4, 6, 7), poprzez wprowadzenie sondy na orbitę planety (tzw. Orbiter; np. Mars 2, 5, Mariner 9, Mars Odyssey),

\footnotetext{
${ }^{1}$ Autor do korespondencji/corresponding author: Adam Jaroszewicz, Politechnika Wrocławska, Wybrzeże Wyspiańskiego 27, 50-370 Wrocław, tel.: (71) 3203772, e-mail: adam.jaroszewicz@pwr.wroc.pl

${ }^{2}$ Odległość Marsa od Ziemi w zależności od wzajemnego położenia planet względem Słońca zawiera się od 5,576 $10^{7} \mathrm{~km}(0,37 \mathrm{AU})$ - wielka opozycja do 4,013 $10^{8} \mathrm{~km}(2,52 \mathrm{AU})$ - koniunkcja górna, co odpowiada czasowi ,,przebiegu” fali elektromagnetycznej na trasie Mars - Ziemia $\rightarrow 186 \mathrm{~s}$ (3 min $6 \mathrm{~s}$ - wielka opozycja) i 1337 s (20 min 57 s - koniunkcja górna). 1 AU (j.a.) - jednostka astronomiczna - średnia odległość Ziemi od Słońca, $1 \mathrm{AU}=1,496 \cdot 10^{7} \mathrm{~km}$.
} 
lądowanie próbników na powierzchni (np. Mars 3, Viking 1, 2, Phoenix) i na dostarczeniu autonomicznych ruchomych pojazdów/łazików na powierzchnię planety kończąc (tzw. Lander/Rover; Sojourner, MER-A Spirit, MER-B Opportunity, MSL Curiosity), umożliwiając prowadzenie prac badawczych nie tylko w miejscu lądowania, ale także w najbliższej okolicy $[1,2]$.

W ciągu ostatnich 20 lat nawigacja satelitarna rozwinęła się z nauki ,eksperymentalnej" do dojrzałej technologii, która zrewolucjonizowała globalne systemy nawigacji obiektów ruchomych. Obecnie istnieje możliwość realizacji praktycznie natychmiastowego pozycjonowania i nawigacji oraz łączności dla użytkowników znajdujących się w dowolnym miejscu globu. Diametralnie inaczej sytuacja przedstawia się w przypadku nawigacji i łączności dla obiektów znajdujących się w „głębokiej” przestrzeni kosmicznej lub na powierzchniach innych ciał niebieskich. Nawigacja i łączność z sondami międzyplanetarnymi znajdującymi się w Układzie Słonecznym są obecnie realizowane za pomocą sieci Deep Space Network (DSN) ${ }^{3}$. Najtrudniejsze warunki do łączności kosmicznej występują nie tylko w przypadku dalekich misji kosmicznych w odległe rejony Układu Słonecznego, ale także dla misji bliskich w okolice Wenus, Merkurego lub Słońca. W pierwszym przypadku występują znaczne ograniczenia mocy sygnałów użytecznych ze względu na odległość, w drugim zaś wpływ silnych zakłóceń elektromagnetycznych ze strony Słońca [3].

Systemy łączności ze statkami kosmicznymi zapewniają dwukierunkową transmisję danch, systemy nawigacji pozwalają określić położenie obiektu w przyjętym układzie współrzędnych [3, 4]. Nawigacja statku kosmicznego w przestrzeni kosmicznej ma na celu:

- określenie aktualnego położenia i planowanej trajektorii lotu,

- określenie parametrów pracy zespołu napędowego (np. ciąg, czas pracy), korekcja aktualnej trajektorii lotu (np. wprowadzenie na orbitę wokół planety - cel podróży).

Systemy nawigacji kosmicznej pozwalają określić m.in. prędkość lotu sondy międzyplanetarnej (w kierunku zgodnym lub przeciwnym do ruchu Ziemi), odległość od Ziemi, położenie w przyjętym układzie współrzędnych (np. położenie na tle nieba) oraz położenie w odniesieniu do celu misji (np. planety) poprzez wykonanie np. serii zdjęć (Optical Navigation, OpNav) - obserwacja miejsca docelowego (np. powierzchni planety) celem dokonania np. niezbędnych korekcji trajektorii lotu przed lądowaniem [5]. Prędkość lotu sondy międzyplanetarnej jest określana na podstawie „,przesunięcia Dopplera”, odległość zaś od Ziemi na podstawie czasu ,przebiegu” zakodowanego (kod czasowy

\footnotetext{
${ }^{3}$ Deep Space Network (DSN) - nadawczo-odbiorcza globalna sieć dużych anten zarządzana przez Jet Propulsion Laboratory (USA). DSN pozwala na nawiązanie łączności pomiędzy Ziemią a bezzałogowymi sondami kosmicznymi eksplorującymi Układ Słoneczny za pośrednictwem sieci przekaźników z antenami o średnicy 34 i 70 m rozmieszczonymi w trzech kompleksach oddalonych od siebie o ok. $120^{\circ}$ - Madryt (Hiszpania), Canberra (Australia) i Goldstone (Kalifornia, USA).
} 
- Time code) sygnału transmitowanego z Ziemi i retransmitowanego ${ }^{4}$ przez nadajnik pokładowy w kierunku powrotnym. Przy znanym opóźnieniu ,wnoszonym" przez systemy pokładowe sondy i urządzenia naziemne oraz przy uwzględnieniu wpływu atmosfery ziemskiej (np. refrakcja jonosferyczna) możliwe jest określenie odległości Ziemia - sonda międzyplanetarna $\mathrm{z}$ dokładnością do pojedynczych metrów. Położenie kątowe w przyjętym układzie odniesienia oraz prędkość opierając się na przesunięcie Dopplera, są realizowane metodą opóźnienia grupowego lub metodą VLBI [3, 4, 6].

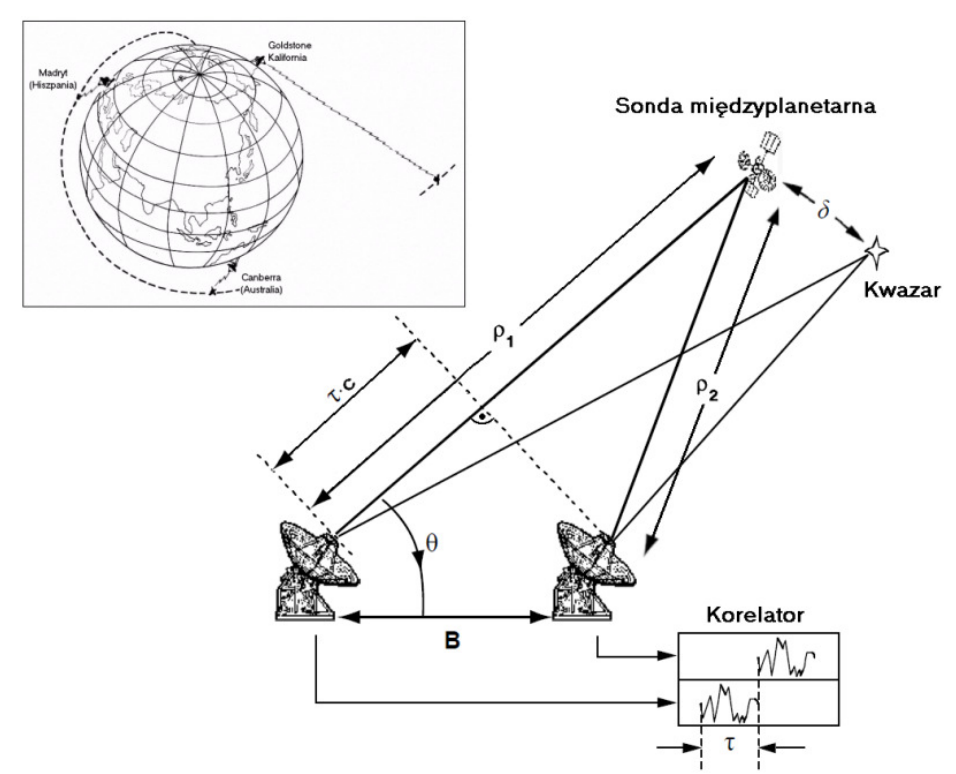

Rys. 1. Metoda VLBI określania odległości za pośrednictwem sieci Deep Space Network

Fig. 1. The VLBI method of distance determination using Deep Space Network

Pomiar położenia kątowego sondy międzyplanetarnej metodą $\mathrm{VLBI}^{5}$ polega na jednoczesnym odbiorze sygnałów transmitowanych przez sondę przez dwa niezależne odbiorniki DSN umieszczone na powierzchni Ziemi, oddalone od

\footnotetext{
${ }^{4}$ Pasmo $X$ - łączność Ziemia - statek kosmiczny $f=7,145 \div 7,235 \mathrm{GHz}$, statek kosmiczny - Ziemia $f=8,400 \div 8,500 \mathrm{GHz}$, pasmo $S$ - łączność Ziemia - statek kosmiczny $f=2,025 \div 2,120 \mathrm{GHz}$, statek kosmiczny - Ziemia $f=2,200 \div 2,300 \mathrm{GHz}$. Pasmo $K a$ - lączność Ziemia - statek kosmiczny $f=34,200 \div 34,700 \mathrm{GHz}$, statek kosmiczny - Ziemia $f=31,800 \div 32,300 \mathrm{GHz}$. Częstotliwość sygnału retransmitowanego z pokładu sondy międzyplanetarnej jest ,przesunięta” do częstotliwości sygnału odbieranego w stosunku: pasmo $S-240 / 221$, pasmo $X-880 / 749$, pasmo $K a-3344 / 3599$.

${ }^{5}$ VLBI (Very - Long - Baseline Interferometry) - interferometria wielkobazowa. Proces ten wymaga znajomości dokładnego położenia każdej stacji DSN w odniesieniu do lokalizacji osi ziemskiej - współcześnie błąd ten nie przekracza $3 \mathrm{~cm}$.
} 
siebie o odległość $B$ (tzw. baza). W procesie detekcji koherentnej odebrane sygnały zostają poddane procesowi korelacji. Do dwóch odbiorników docierają dwa identyczne sygnały transmitowane przez sondę przesunięte w fazie ze względu na różnice dróg $\rho_{1}$ i $\rho_{2}$. Pomiar przesunięcia fazowego pomiędzy sygnałami (proces korelacji) umożliwia określenie ich wzajemnego opóźnienia $\tau$ i kąta podniesienia anteny $\theta-\Delta \mathrm{DOR}^{6}$ (rys. 1.).

$$
\rho_{1}-\rho_{2}=B \cdot \sin \theta \rightarrow \tau \cdot c=B \cdot \sin \theta \rightarrow \sin \theta=\tau \cdot c / B
$$

Takie rozmieszczenie odbiorników DSN pozwala, na podstawie pomiaru przesunięcia fazowego fali elektromagnetycznej, zmierzyć kąt $\theta$ pomiędzy prostą wyznaczaną przez anteny w zakresie od $0^{\circ}$ do $180^{\circ}$ a umowną linią łączącą antenę z sondą międzyplanetarną (tzw. linia namiaru). Wykorzystanie metod triangulacji umożliwia określenie położenia przestrzennego sondy międzyplanetarnej, jednakże z powodu „niedokładnego” ustawienia anteny w kierunku sondy sam pomiar jest obarczony znacznym błędem. Jako obiekty odniesienia (Reference source) służą m.in. kwazary, których pozycje przestrzenne są dokładnie określone metodami astronomicznymi (odległość kątowa $\leq 15^{\circ}$ ). Współcześnie dokładność określania pozycji w rejonie Układu Słonecznego (VLBI) jest szacowana na ok. $5 \mathrm{nrad}$ (750 m na odległości 1 AU) [7, 8].

\section{Nawigacja i łączność z Marsem - stan obecny}

Współcześnie nawigacja i łączność z sondami krążącymi wokół Marsa i łazikami poruszającymi się po jego powierzchni jest realizowana za pomocą sieci DSN. Wzajemna odległość Ziemi i Marsa zmienia się prawie 7-krotnie w zależności od wzajemnego położenia planet, co ma znaczący wpływ na jakość transmisji. Przy odległościach powyżej 2,45 AU (planety po przeciwnych stronach Słońca) zakłócenia wnoszone przez gwiazdę praktycznie uniemożliwiają realizację łączności radiowej Mars - Ziemia [2]. Szybkość bezpośredniej transmisji danych na trasie Mars - Ziemia z pokładów łazików marsjańskich zależy m.in. od mocy pokładowych źródeł energii elektrycznej. Ograniczona pojemność lądownika determinuje rozmiary samego łazika, a także rozmiary i moc pokładowych źródeł energii elektrycznej. Problem deficytu mocy elektrycznej w znacznie mniejszym stopniu występuje w przypadku orbiterów - sztucznych satelitów Marsa krążących po orbicie wokółmarsjańskiej. Dwa „aktywne” sztuczne satelity Marsa: Mars Odyssey i Mars Reconnaissance Orbiter są zasilane za pośrednictwem paneli ogniw fotoelektrycznych: Mars Odyssey $-P_{\text {zasil } \max }=750 \mathrm{~W}$, Mars Reconnaissance Orbiter $-P_{\text {zasil } \max }=2000 \mathrm{~W}$. Pozwala to na zwiększenie mocy nadajników pokładowych, co jest równoznaczne ze

\footnotetext{
${ }^{6} \Delta \mathrm{DOR}$ - Delta Differential One-way Range - różnicowa metoda pomiaru odległości poprzez jednokierunkową emisję fali elektromagnetycznej, np. sonda międzyplanetarna - Ziemia.
} 
wzrostem szybkości transmisji danych: Mars Reconnaissance Orbiter $-P_{\mathrm{NAD}}=$ $=100 \mathrm{~W}(\mathrm{X}), 35 \mathrm{~W}(\mathrm{Ka})$; szybkość transmisji z Ziemią $0,5 \div 3,5 \mathrm{Mb} / \mathrm{s}$, Mars Odyssey $-P_{\mathrm{NAD}}=15 \mathrm{~W}(X)$; szybkość transmisji z Ziemią $128 \div 256 \mathrm{~kb} / \mathrm{s}$. Dodatkowo sztuczne satelity Marsa uczestniczą w retransmisji danych z/na pokład łazików marsjańskich, co pozwala na ograniczenie mocy nadajników pokładowych łazików (ograniczenie zużycia energii elektrycznej) i wzrost szybkości transmisji ${ }^{7}$. Wysokość orbity sztucznych satelitów Marsa, np. Mars Reconnaissance Orbiter $-h=250 \div 316 \mathrm{~km}$, umożliwia transmisję danych na Ziemię przez czas $10 \div 11 \mathrm{~h} / \mathrm{SOL}$ (rys. 2.) [2, 9].

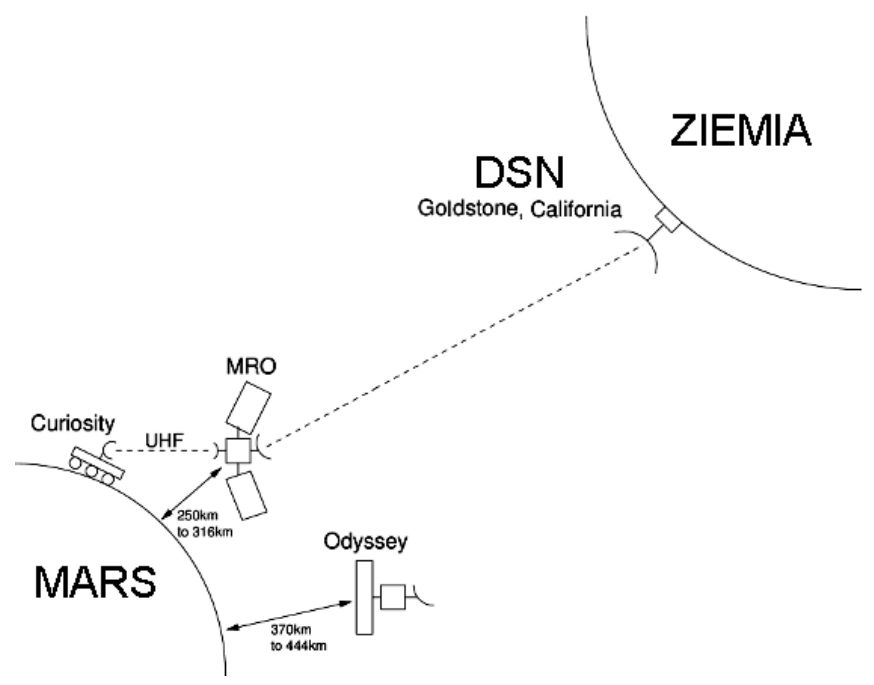

Rys. 2. System transmisji danych $\mathrm{z}$ pokładów sond i łazików marsjańskich

Fig. 2. The data transmission system from deck of Mars probes and exploration rovers

\section{Nawigacja i łączność z Marsa - przyszłość}

Współczesna nawigacja sond międzyplanetarnych znajdujących się w dalekiej przestrzeni kosmicznej jest procesem złożonym, czasochłonnym i kosztownym, wymagającym do pracy rozbudowanej infrastruktury naziemnej. Sam proces nawigacji jest całkowicie nieautonomiczny; sonda nie jest w stanie, wykorzystując aparaturę pokładową, określić swojego położenia przestrzennego w przyjętym układzie odniesienia. DSN zapewnia doskonałe możliwości nawigacyjne. Jednak pozwala na jednoczesne prowadzenie nawigacji tylko czterech

\footnotetext{
${ }^{7}$ Podczas 9 min z pokładu łazika, np. MSL - Curiosity do Mars Recoinaissance Orbiter MRO (Mars Odyssey Orbiter) zostanie przesłanych maksymalnie $8 \div 9 \mathrm{MB}$ danych; identyczna liczba danych będzie przesyłana bezpośrednio $\mathrm{z}$ łazika na Ziemię od 1,5 do $5 \mathrm{~h}$.
} 
obiektów znajdujących się na powierzchni Marsa; możliwości te są ograniczone przez prędkość rozchodzenia się fal elektromagnetycznych. Czas ten staje się kluczowym zagadnieniem, gdy np. lądownik sondy „wchodzi” w końcową fazę lądowania, np. na powierzchni Marsa. W pewnym momencie czas trwania procedury lądowania będzie krótszy, niż czas potrzebny do przesłania przez DSN na pokład lądownika (lądownik - Ziemia DSN - lądownik) niezbędnych korekt nawigacyjnych, co może mieć decydujący wpływ na powodzenie misji. Dla zdalnej nawigacji sond międzyplanetarnych prowadzonych przez DSN z powierzchni Ziemi praktycznie niemożliwy staje się dokładny rozdział systemów pokładowych sond na systemy nawigacji i systemy łączności (transmisji danych). Przykładowo, nawigacja optyczna OpNav jest prowadzona podczas podejścia do lądowania (np. zdjęcia powierzchni Marsa), zdjęcia są przesyłane przez system łączności DSN (transmisja danych) do stacji naziemnych, gdzie jest prowadzona procedura określenia położenia sondy względem trajektorii lądowania (nawigacja), następnie zaś sygnały korekcyjne przez system łączności (transmisja danych) są przesyłane do systemów pokładowych sondy odpowiedzialnych za orientację w przestrzeni.

Współcześnie funkcjonujące ziemskie systemy nawigacji satelitarnej (GPS, GLONASS, BEIDOU) są także systemami nawigacji i transmisji danych, przy czym dla szerokiego spektrum użytkowników jest udostępniona jedynie funkcja nawigacji. Poszczególne satelity wymienionych systemów tworzą rozbudowaną sieć transmisji danych na trasie: Ziemia - satelita nawigacyjny - Ziemia, a także pomiędzy satelitami systemu nawigacyjnego. Uaktualnienie danych nawigacyjnych retransmitowanych z pokładów satelitów nawigacyjnych do użytkowników jest realizowane przez system łączności (transmisja danych) pomiędzy satelitami i stacjami naziemnymi. Już system Transit umożliwiał (oprócz nawigacji) retransmisję informacji pomiędzy uprzywilejowanymi użytkownikami systemu (US Navy). Przyszłościowy europejski system nawigacji satelitarnej Galileo będzie oferował, oprócz trybu nawigacji, także tryb łączności i transmisji danych - serwis poszukiwania i ratowania SAR (Search and Rescue Service). Satelitarny system nawigacyjny, jakim bez wątpienia jest np. system GPS, jest de facto systemem transmisji danych. Określanie pozycji użytkownika systemu jest realizowane w odbiorniku nawigacyjnym, zabudowanym np. w telefonie GSM trzymanym w ręce przez użytkownika, na podstawie danych nawigacyjnych opracowanych w stacji segmentu naziemnego (główna stacja nadzoru - baza sił lotniczych Shriever AFB w Colorado Springs, USA), retransmitowanych przez sieć sztucznych satelitów systemu GPS w skali całego globu. Obecnie w różnych miejscach Układu Słonecznego znajduje się 9 „,czynnych” obiektów ${ }^{8}$, z którymi jest utrzymywana łączność i prowadzona nawigacja za pośrednictwem sieci

\footnotetext{
${ }^{8}$ Voyager 1, Voyager 2, Cassini Huygens, New Horizons, Mars Express, Mars Odyssey Orbiter, Mars Reconnaissance Orbiter, MER Opportunity, MSL - Curiosity.
} 
$\mathrm{DSN}^{9}$. Znaczny wzrost liczby i różnorodności misji badawczych, „bogactwo” instrumentów pokładowych i informacji gromadzonych w pamięciach lądowników / łazików, spowoduje zwiększenie liczby danych i wymusi konieczność wzrostu szybkości transmisji pomiędzy próbnikami operującymi zarówno w rejonie Marsa, jak i z Ziemią. Załogowa wyprawa na Marsa postawi przed projektantami całkowicie nowe wyzwania dotyczące transmisji danych z głębokiej przestrzeni kosmicznej, tj. zapewnienie ciągłej, szerokopasmowej transmisji danych o przepustowości co najmniej $50 \div 100 \mathrm{Mb} / \mathrm{s}$.

Reasumując, proces stałej eksploracji Marsa, którego ukoronowaniem ma być załogowa wyprawa na Marsa, będzie wymagać budowy w pełni autonomicznego i niezawodnego systemu nawigacji i łączności (transmisji danych) w skali całej planety. Marsjański system nawigacji i łączności powinien zapewnić m.in. [10]:

- możliwość określenia pozycji (informacje nawigacyjne) użytkownika $\mathrm{z}$ wymaganą dokładnością $\mathrm{w}$ skali całego globu ${ }^{10}$ na powierzchni planety $\mathrm{i}$ w bliskiej przestrzeni kosmicznej (np. wspomaganie nawigacyjne w krytycznych fazach lotu, lądowanie na powierzchni planety),

- retransmisję danych z pokładów lądowników / łazików na Ziemię - wzrost prędkości transmisji (łącze laserowe) - ograniczenie mocy / zużycia energii przez lądowniki / łaziki marsjańskie,

- retransmisję danych pomiędzy np. lądownikami, łazikami, balonami, samolotami w skali całej planety (np. badania geologiczne, meteorologiczne),

- globalne wsparcie w zakresie łączności i transmisji danych dla wielu użytkowników (np. członkowie załóg),

- minimalizację zmienności pokrycia powierzchni planety i błędów określania pozycji użytkowników z powodu długoterminowych perturbacji orbit satelitów systemu,

- maksymalną efektywność dla danej konstelacji satelitów oraz sprawność systemu w przypadku np. ,utraty” jednego z satelitów nawigacyjnych.

W wyborze optymalnego, satelitarnego systemu nawigacyjnego dla Marsa należy kierować się m.in.:

- zasięgiem i niezawodnością funkcjonowania systemu,

- dokładnością i szybkością określania pozycji użytkowników,

- dostępnością i liczbą użytkowników,

${ }^{9}$ Maksymalna prędkość transmisji danych na trasie orbita marsańska - Ziemia nie przekracza 3,5 Mb/s przy ograniczeniach czasowych do ok. $11 \mathrm{~h} / \mathrm{SOL}$, wynikających z ruchu obrotowego planety. Przy tej prędkości „,przesłanie” jednego zdjęcia powierzchni Marsa w wysokiej rozdzielczości na Ziemię zajmuje ok. 90 min, co pozwala na przesłanie ok. 7 zdjęć / SOL.

${ }^{10}$ Dotychczasowa eksploracja Marsa prowadzona za pośrednictwem lądowników i łazików była skupiona głównie na równikowym pasie powierzchni planety zawartej pomiędzy zwrotnikami (dla Marsa $\left.-24,936^{\circ} \mathrm{N} \div 24,936^{\circ} \mathrm{S}\right)$. 
- autonomicznością i możliwością „zdalnej” konfiguracji elementów systemu,

- liczbą satelitów i stacji monitorujących systemu nawigacyjnego.

Szacuje się, że w czasie pierwszego etapu eksploracji Marsa liczba użytkowników systemu nawigacyjnego nie przekroczy kilkunastu, kilkudziesięciu odbiorców.

Kolejnym celem jest wybór metody określania powierzchni pozycyjnych ${ }^{11}$, która ma bezpośredni wpływ na organizację systemu nawigacyjnego, a pośredni na jego autonomiczność. ,Ziemskie” satelitarne systemy nawigacyjne, wykorzystujące głównie metodę odległościową (GPS, GLONASS, GALILEO) ${ }^{12}$, umożliwiają określenie położenia $\mathrm{w}$ dowolnym punkcie globu w czasie nieprzekraczającym kilku minut z dokładnością kilku metrów. Dokładność i szybkość określania pozycji jest jednak odkupiona rozbudowaną strukturą kosmiczną i naziemną systemów (GPS - 24 satelity, 12 stacji naziemnych, GLONASS - 24 satelity, 6 stacji naziemnych, GALILEO - 27 satelitów, 5 stacji naziemnych). Marsjański system nawigacyjny ma być systemem „bezobsługowym”, w pełni autonomicznym, którego dane nawigacyjne retransmitowane do użytkowników są opracowywane nie na powierzchni Marsa, lecz na Ziemi i retransmitowane do satelitów systemu poprzez sieć DSN. Dlatego też w pierwszym etapie eksploracji Marsa ${ }^{13}$ dokładność i szybkość określania pozycji na powierzchni Marsa wydaje się być celem drugorzędnym ${ }^{14}$ na rzecz zasięgu i niezawodności satelitarnego systemu nawigacyjnego. Dokonując analizy „ziemskich” systemów nawigacji satelitarnej pod kątem minimalnej liczby satelitów niezbędnych do określenia pozycji użytkownika, autonomiczności systemu i liczby stacji naziemnych „obsługujących” dany system nawigacyjny, najbardziej korzystnym rozwiązaniem w pierwszym etapie eksploracji Marsa wydaje się być dopplerowski system nawigacji satelitarnej ${ }^{15}$.

${ }^{11}$ Powierzchnia pozycyjna - miejsca geometryczne punktów w przestrzeni odpowiadające stałej wartości mierzonego parametru (np. kąta, odległości) - dla metody odległościowej powierzchnia kuli, w środku której znajduje się sztuczny satelita. Współcześnie w radionawigacji jest znanych pięć metod określania powierzchni pozycyjnych (kątowa, odległościowa, różnic odległości, pomiaru prędkości radialnej satelity, dopplerowska), jednak tylko dwie odczekały się praktycznego zastosowania: metoda dopplerowska (TRANSIT) i metoda odległościowa (np. GPS, GLONASS, GALILEO).

${ }^{12}$ Określenie położenia użytkownika (punkt przecięcia się powierzchni pozycyjnych) przez pomiar odległości pomiędzy kilkoma satelitami systemu nawigacyjnego (efemerydy satelitów (współrzędne) w informacji nawigacyjnej) a obserwatorem.

${ }^{13}$ Misje marsjańskie do chwili lądowania ludzi na powierzchni planety bez budowy stałej bazy załogowej na powierzchni.

${ }^{14}$ Dokładność określania pozycji rzędu 1-2 km w czasie 60-120 min wydaje się do zaakceptowania na bezdrożach Marsa.

15 Jedynym istniejącym systemem nawigacji satelitarnej wykorzystującym zjawisko Dopplera był „nieczynny już” system TRANSIT opracowany na początku lat 60 . XX w. przez USA na potrzeby amerykańskiej flotylli łodzi podwodnych Polaris. W 1968 roku system został oddany do użytku cywilnego pod nazwą NNSS (Naval Navigation Satellite System). System tworzyło 6 (7 od 1988 r.) satelitów nawigacyjnych, rozmieszczonych na sześciu orbitach kołowych, biegunowych $(h=1100$ 
Systemy dopplerowskie opierają się na pomiarze szybkości zmiany odległości od użytkownika do nadajnika, którą określa częstotliwość Dopplera dla sygnału emitowanego z pokładu satelity [11]. Wielkość dopplerowskiego przesunięcia częstotliwości dla danego miejsca jest wprost proporcjonalna do prędkości ruchu względnego satelity $v_{s}$ i użytkownika. Przecięcie się powierzchni stożkowej (powierzchni pozycyjnej) odpowiadającej stałej wartości dopplerowskiego przesunięcia częstotliwości z powierzchnią planety (np. Marsa) wyznacza linię pozycyjną, zwaną izodoppą (rys. 3.). Prędkość $v_{d}$ oblicza się na podstawie dopplerowskiego przesunięcia częstotliwości sygnału odbieranego z satelity. Określenie pozycji użytkownika jest analogiczne do metody wykorzystanej w hiperbolicznych systemach nawigacyjnych, w których tzw. baza (odległość pomiędzy stacjami bazowymi systemu - nadajnikami radiowymi) jest równa odległości ,pokonywanej” przez jednego satelitę w wybranym przedziale czasu, $S_{1} \div S_{n}$ (tzw. punkty bazowe, np. satelity systemu Transit pokonywały w ciągu $1 \mathrm{~s}$ odległość ok. $44 \mathrm{~km}$ ). Położenie użytkownika na powierzchni Ziemi określa się poprzez odniesienie go do ,znanej” orbity satelity nawigacyjnego (efemerydy satelity). W celu określenia pozycji użytkownika w układzie współrzędnych geograficznych należy określić miejsce, w którym dopplerowska zmiana częstotliwości zmienia znak, czyli przechodzi przez zero (rys. 4.). W wyniku względnego ruchu satelity nawigacyjnego i użytkownika otrzymuje się tzw. krzywe zmian częstotliwości dopplerowskiej, których kształt zależy od odległości użytkownika od płaszczyzny orbity satelity. W pobliżu punktu kulminacji występują coraz szybsze zmiany częstotliwości odbieranej, które w granicznym przypadku będą występować nieskończenie szybko w granicach od $f_{\mathrm{N}}+f_{\mathrm{D}}$ do $f_{\mathrm{N}}-f_{\mathrm{D}}$ (satelita znajduje się dokładnie nad lub najbliżej odbiornika).

Rys. 3. Linie i powierzchnie pozycyjne w dopplerowskim systemie nawigacji satelitarnej: linia $A-B$ - izodoppa (położenie użytkownika systemu), $S$ - punkt bazowy

Fig. 3. Position lines and surfaces in Doppler satellite navigation system: $A-B$ line - isodoppa (position of system user), $S$ - base point

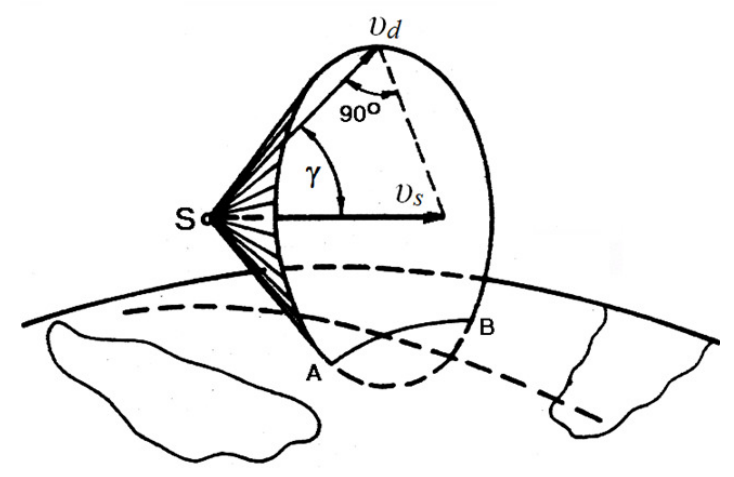

$\mathrm{km}$ ) przesuniętych względem siebie o $30^{\circ}$, nadających w sposób ciągły sygnały zawierające dokładny aktualny czas oraz parametry swojej orbity (efenerydy). System był obsługiwany przez pięć stacji naziemnych. Informacja nawigacyjna odebrana z jednego satelity w kilku następujących po sobie odstępach czasu umożliwiała określenie pozycji odbiornika z dokładnością do 0,1 mili morskiej w skali całego globu. 


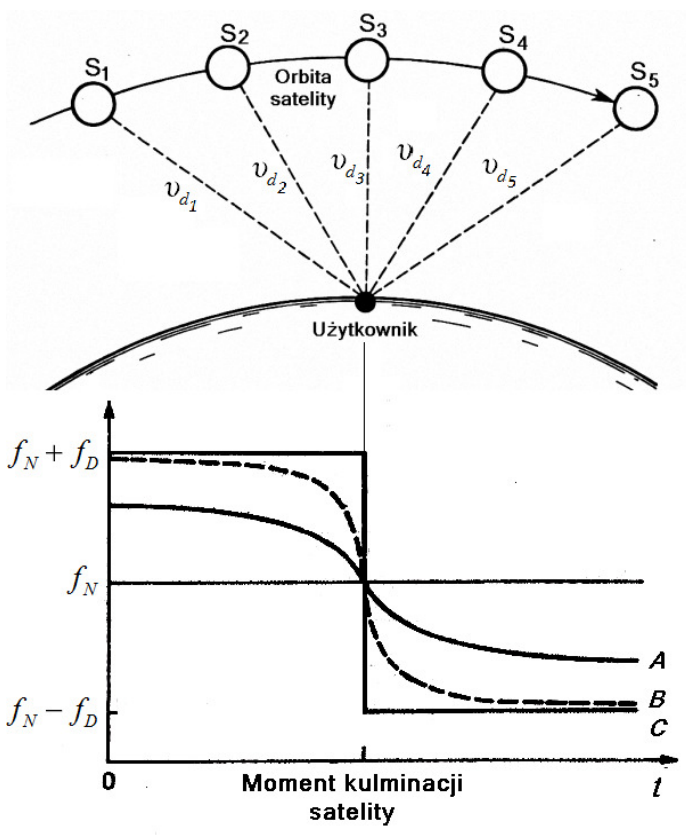

Rys. 4. Zmiany częstotliwości sygnałów odbieranych z satelity - efekt Dopplera: $S_{1} \div S_{5}-$ kolejne położenia satelity, $A, B, C$ - odległości odbiornika od satelity ( $A$ największa, $C$ - najmniejsza)

Fig. 4. Variation of frequency of signals emitted by satellite - Doppler effect, $S_{1} \div S_{5}-$ following satellite positions, $A, B, C$ - the distance between the receiver and satellite ( $A$ - the largest, $C$ - the smallest)

System Transit wykorzystywał sześć satelitów nawigacyjnych rozmieszczonych na sześciu kołowych orbitach biegunowych ${ }^{16}$, poruszających się na wysokości ok. $h=1100 \mathrm{~km}$. Satelity nawigacyjne systemu Transit okrążały Ziemię w czasie ok. $108 \mathrm{~min}(13,5 \mathrm{razy} / 24 \mathrm{~h})$. Ze względu na rozmieszczenie orbit satelitów każdy odbiornik nawiązywał jednoczesną łączność przeważnie tylko z jednym satelitą systemu. Poprawka położenia mogła być wyznaczona dopiero po tym, jak kolejny satelita znalazł się nad horyzontem podczas wykonywania kolejnego okrążenia i odbiornik ponownie nawiązał łączność z tym satelitą. Na średnich szerokościach geograficznych wymagało to jedno- lub dwugodzinnego oczekiwania na pojawienie się następnego satelity i wyznaczenie kolejnej pozycji, a w okolicach równika - kilkugodzinnego oczekiwania. Transit nie był w stanie realizować dynamicznego (w czasie rzeczywistym) określenia pozycji odbiornika użytkownika $[6,12,13]$.

Główną zaletą dopplerowskiego systemu nawigacyjnego jest możliwość określenia pozycji użytkownika $\mathrm{z}$ wykorzystaniem sygnałów tylko $\mathrm{z}$ jednego satelity (systemy odległościowe np. GPS wymagają w przypadku nawigacji 2D - minimum trzech satelit, 3D - minimum czterech satelit), wadą zaś długi czas i niska dokładność wyznaczania pozycji. Odnosząc parametry systemu Transit

${ }^{16}$ Orbita, której płaszczyzna pokrywa się z płaszczyzną południka lokalnego. Satelita poruszający się po orbicie biegunowej przelatuje co pewien czas nad dwoma biegunami ciała centralnego. Orbita taka, w zależności od jej promienia, przecina płaszczyznę równika przy każdym obiegu w innym miejscu (Mars), przy każdym obiegu satelity obraca się o stały kąt. Umożliwia to obserwację całej powierzchni planety. 
do warunków marsjańskich, zakładając 12 okrążeń planety w ciągu trwania doby marsjańskiej - SOL, czas jednego okrążenia planety $T_{S M}$ i wysokość orbity satelitów $h_{S}$ są równe:

$$
T_{S M}=\mathrm{SOL} / 12 \rightarrow 7398 \mathrm{~s}, \quad h_{S}=\sqrt[3]{\left(\frac{T_{S M} \cdot \sqrt{\mu_{M}}}{2 \pi}\right)^{2}}-R_{M} \rightarrow h_{S}=509 \mathrm{~km}
$$

gdzie: $\mu$ - parametr grawitacyjny Marsa, $\mu=G M_{M} \rightarrow \mu=4,275 \cdot 10^{13} \mathrm{~m}^{3} / \mathrm{s}^{2}$, przy czym $G$ - stała grawitacji, $G=6,673 \cdot 10^{-11} \mathrm{~N} \cdot \mathrm{m}^{2} / \mathrm{kg}^{2}, M_{M}$ - masa Marsa, $M_{M}=6,4185 \cdot 10^{23} \mathrm{~kg}$,

$R_{M}$ - średni promień Marsa, $R_{M}=3,389 \cdot 10^{6} \mathrm{~m}$.

Na konfigurację satelitarnego systemu nawigacyjnego (liczba płaszczyzn orbitalnych i satelitów krążących) ma wpływ także na tzw. widzialność satelity nad horyzontem lokalnym ${ }^{17}$. „Przeloty” satelitów, dla których kąty elewacji (wysokość satelity nad horyzontem) w punkcie kulminacji są mniejsze niż $5^{\circ}$ lub większe niż $80^{\circ}$, nie są wykorzystywane do celów nawigacyjnych. Kąt $\eta$ określający strefę widzialności satelity:

$$
\eta=\arccos \frac{R_{M}}{R_{M}+h_{S}} \rightarrow \eta=29,6^{\circ} \rightarrow 2 \eta=59,2^{\circ} \Rightarrow r=1757,7 \mathrm{~km}
$$

Obszar łączności z satelitą Marsa znajdującego się na orbicie kołowej o wysokości $h_{S}=509 \mathrm{~km}$ w najkorzystniejszym układzie geometrycznym (użytkownik znajduje się $\mathrm{w}$ płaszczyźnie orbity satelity) jest równy $2 \eta=59,2^{\circ}$; obejmie powierzchnię Marsa ograniczoną okręgiem o promieniu $r=1757,7 \mathrm{~km}$ (rys. 5.).

Rys. 5. Strefa widzialności $\eta$ satelity $S$ przez obserwatora $O: S_{M}$ - środek Marsa, $R_{M}$ - promień Marsa, $h_{S}$ - wysokość satelity nad powierzchnią Marsa

Fig. 5. Visibility zone $\eta$ of $S$ satellite by observer $O$ : $S_{M}$ - Mars centre, $R_{M}$ - Mars radius, $h_{S}$ - height of the satellite over the Mars surface

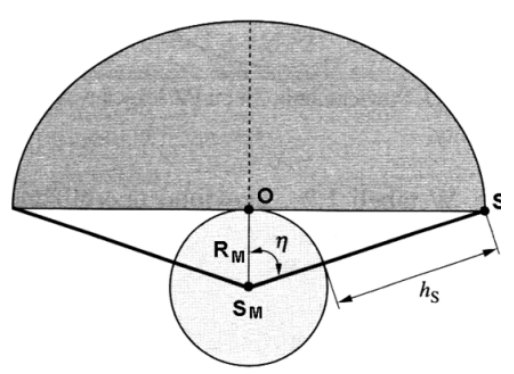

${ }^{17}$ Widzialność satelity jest, pomijając ujemny wpływ refrakcji troposferycznej (załamania wiązki promieniowania elektromagnetycznego), równoważna $\mathrm{z}$ możliwością nawiązania przez użytkownika łączności z satelitą - obszar łączności z satelitą. 
Minimalna liczba satelitów nawigacyjnych $K$ dla założonego czasu oczekiwania $\Delta t_{S}=120 \mathrm{~min}$ na ,przelot" satelity i określenie pozycji użytkownika jest równa [6]:

$$
K=\frac{\pi\left(180^{\circ}\right) \cdot T_{S M}}{\Delta t_{S} \cdot 2 \eta} \rightarrow \frac{180^{\circ} \cdot 123,3 \min (7398 \mathrm{~s})}{120 \min \cdot 59,2^{\circ}} \rightarrow 3,12 \rightarrow 4
$$

Minimalna liczba satelitów jest równa 4; zwiększenie tej liczby przy ustalonych parametrach orbity skróci czas oczekiwania $\Delta t_{s}$. Projektowany system nawigacyjny Marsa tworzy 6 satelitów poruszających się na średniej wysokości $h_{S M}=509 \mathrm{~km}$ (3898 km od środka planety) na 6 kołowych, biegunowych orbitach, których płaszczyzny są przesunięte co $30^{\circ}$ długości geograficznej, tzw. długości areograficznej węzła wstępującego ${ }^{18}$ (względem równika Marsa ${ }^{19}$ ). Opierając się na równaniu (4), otrzyma się średni czas oczekiwania $\Delta t_{S}$ dla 6 satelitów: $\Delta t_{S}=62,5 \mathrm{~min}$. Dodatkowe przesunięcie satelitów na sąsiednich orbitach w płaszczyźnie południkowej o kąt $30^{\circ}$ (np. satelita $1 .-90^{\circ} \mathrm{S}, 0^{\circ} \mathrm{E}$, satelita 2. $-60^{\circ} \mathrm{S}, 30^{\circ} \mathrm{E}$, satelita $3 .-30^{\circ} \mathrm{S}, 60^{\circ} \mathrm{E}$, satelita $4 .-0^{\circ} \mathrm{N}, 90^{\circ} \mathrm{E}$, satelita $5 .-30^{\circ} \mathrm{N}, 120^{\circ} \mathrm{E}$, satelita $6 .-60^{\circ} \mathrm{N}, 150^{\circ} \mathrm{E}$ (współrzędne określają rzut pozycji satelity na powierzchnię Marsa)) skróci czas oczekiwania i zapewni optimum widzialności, długości obserwacji i dokładności wskazań (rys. 6.).

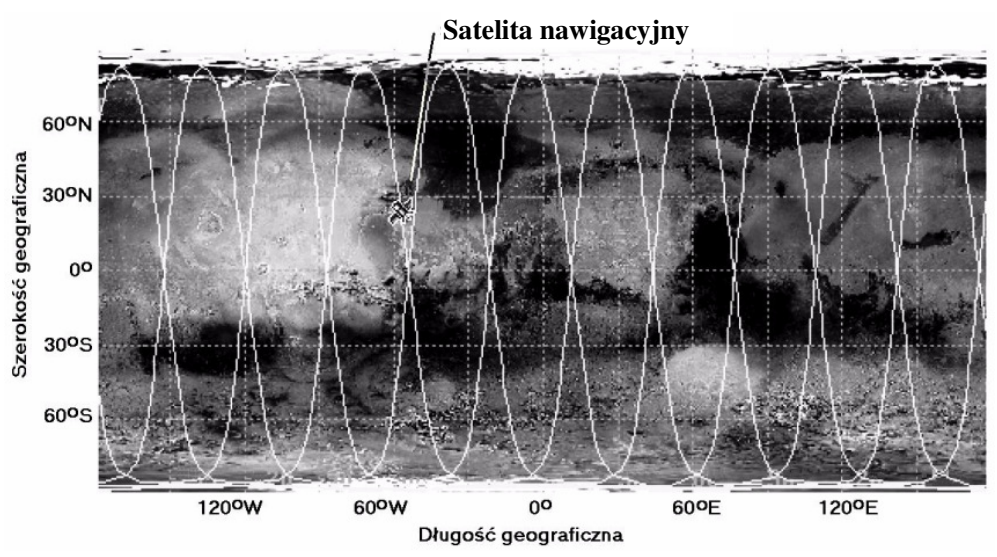

Rys. 6. Przykładowy rzut trajektorii satelitów nawigacyjnych na powierzchnię Marsa

Fig. 6. The example of the projection of navigation satellite trajectory on Mars surface

\footnotetext{
${ }^{18}$ Punkt, w którym projekcja orbity sztucznego satelity na sferę niebieską przecina się z równikiem niebieskim; satelita poruszający się po orbicie z południa na północ przecina płaszczyznę równika niebieskiego i ,przechodzi” na północną półkulę niebieską (dodatnia deklinacja satelity).

19 Długość równika Marsa: $l_{R M}=21378 \mathrm{~km}$.
} 
Każdy satelita powinien obejmować swoim zasięgiem pas powierzchni Marsa o szerokości równoleżnikowej $30^{\circ}$, co przy teoretycznej strefie widzialności $2 \eta=59,2^{\circ}$ umożliwi użytkownikowi znajdującemu się $\mathrm{w}$ strefie równikowej nawiązanie łączności z dowolnym satelitą systemu w czasie do $60 \mathrm{~min}$. Utrata jednego satelity systemu, nie wpłynie znacząco na dokładność, może jedynie wydłużyć się czas określania pozycji. Wpływ na dokładność określania pozycji użytkownika ma także stabilność częstotliwości sygnału emitowanego z satelitów. Stabilizacja częstotliwości z dokładnością $10^{-10} \mathrm{~s}$ spowoduje, że dla częstotliwości nośnej nadajnika satelity $f_{N}=100 \mathrm{MHz}$ niedokładność dopplerowskiej zmiany częstotliwości $f_{D}=1 \mathrm{~Hz}$ daje błąd położenia rzędu ok. $1 \mathrm{~min}$ kątowej (dla Marsa 0,989 km). Wpływ refrakcji jonosferycznej na wynik pomiaru może być kompensowany zastosowaniem dwóch częstotliwości nośnych $f_{N 1}$ i $f_{N 2}$ (wystarczających na małych i średnich szerokościach geograficznych).

System nawigacyjny Marsa musi być systemem w pełni autonomicznym; nie jest możliwa częsta korekcja położenia satelitów na orbitach, jak ma to miejsce w przypadku systemów ziemskich, lub korekcja oprogramowania nawigacyjnego transmitowanego do użytkowników. Autonomiczność tę zwiększa możliwość umieszczenia wszystkich satelitów systemu na orbitach tworzących tzw. konstelację Walkera (jednorodna i spójna fazowo konstelacja satelitów na identycznych orbitach biegunowych), w której wszystkie zakłócenia ruchu satelitów, np. grawitacyjne, wpływają w równym stopniu na wszystkie satelity systemu. Umożliwia to zachowanie geometrii orbit satelitów bez nadmiernej ingerencji ze strony stacji kontroli (zużycie paliwa $\rightarrow$ silniki korekcyjne). Konstelacja satelitów systemu nawigacyjnego Marsa tworzy konstelację Walkera 90:6/6/1 ${ }^{20}$. Proces budowy w pełni funkcjonalnego systemu nawigacji satelitarnej Marsa będzie przedsięwzięciem wieloletnim, wieloetapowym $[11,14,15]$ :

- etap 1. - lądowanie na powierzchni Marsa kilku bezzałogowych lądowników stanowiących stacje kontroli i sterowania systemem nawigacyjnym, lokalizacja położenia poszczególnych lądowników w marsjańskim układzie współrzędnych (za pośrednictwem orbiterów krążących po orbitach Marsa/DSN) $)^{21}$ (tab. 1.),

- etap 2. - wystrzelenie na biegunowe orbity Marsa konstelacji satelitów nawigacyjnych, „wstępne” trajektorie orbit określone za pośrednictwem orbiterów Marsa/DSN,

- etap 3. - ustalenie ,dokładnych” trajektorii satelitów nawigacyjnych (efemerydy) z poziomu lądowników, np. poprzez wykorzystanie dalmie-

${ }^{20} 90$ - kąt inklinacji - i, 6 - liczba satelitów systemu, 6 - liczba płaszczyzn orbitalnych (równomiernie rozmieszczonych), $l$ - względna odległość pomiędzy sąsiednimi orbitami.

${ }^{21}$ Lądowniki / główne stacje kontroli i sterowania pracą systemu nawigacyjnego wyposażone w wysokostabilne wzorce czasu, zasilane np. przez generatory RTG (niezależność zasilania od warunków zewnętrznych (poziom oświetlenia)) $\rightarrow$ MSL Curiosity. W pierwszej fazie budowy systemu nawigacyjnego możliwe wykorzystanie istniejących lądowników marsjańskich jako pomocniczych stacji kontroli (tab. 1.). 
rzy laserowych (lądowniki); lustra zabudowane na pokładach satelitów nawigacyjnych,

- etap 4. pełna funkcjonalność systemu - lądowniki stanowią stacje kontroli i sterowania pracą systemu nawigacyjnego; okresowa korekcja błędów nawigacyjnych (np. perturbacje orbit satelitów nawigacyjnych) poprzez „korekcję” oprogramowania nawigacyjnego transmitowanego do użytkowników.

System łączności dla Marsa ma za zadanie zapewnienie pełnego i ciągłego pokrycia powierzchni planety i bliskiej przestrzeni kosmicznej siecią bezprzewodowej łączności radiowej w celu wsparcia logistycznego przyszłych załogowych i bezzałogowych misji marsjańskich [7]. System łączności powinien zapewnić utrzymanie ciągłej dwukierunkowej łączności z wymaganą szybkością transmisji danych na dystansie:

- Ziemia (DSN) $\leftrightarrow$ lądownik / łazik / misje załogowe $\rightarrow$ połączenie użytkowników końcowych na Ziemi i na Marsie,

- Ziemia (DSN) $\leftrightarrow$ Mars - satelity systemu nawigacji i łaczności $\rightarrow$ obsługa / konserwacja, np. upgrade oprogramowania przez „kontrolerów” z Ziemi,

- lądownik / łazik / misje załogowe $\leftrightarrow$ lądownik / łazik / misje załogowe $\rightarrow$ wymiana informacji pomiędzy poszczególnymi zespołami badawczymi, np. badania sejsmograficzne w skali całej planety,

- Mars - satelity systemu nawigacji i łaczności ↔ Mars Orbiter (np. satelita areostacjonarny) - transmisja danych w kierunku Ziemi przez satelitę areostacjonarnego - wzrost szybkości transmisji i czasu „łączności” z Ziemią,

- Mars - satelity systemu nawigacji i łączności $\leftrightarrow$ Mars - satelity systemu nawigacji i łączności $\rightarrow$ powiązania krzyżowe pomiędzy satelitami, przydatne dla różnych trybów funkcjonowania sieci, np. transfer danych, przekierowywanie transmisji danych, upgrade efemeryd, synchronizacja czasu systemu, badania atmosfery,

- Mars - satelity systemu nawigacji i łaczności $\leftrightarrow$ sondy międzyplanetarne / misje załogowe na trajektorii lądowania na Marsie / „odlot” w kierunku Ziemi, np. dokładna nawigacja podczas lądowania precyzyjnego.

Szybkość bezprzewodowej transmisji danych jest proporcjonalna m.in. do częstotliwości nośnej, mocy nadajnika i rozmiarów anteny nadawczej. Współcześnie łączność międzyplanetarna jest realizowana w paśmie $X(8 \mathrm{GHz})$, przyszłościowe pasmo $\mathrm{Ka}(32 \mathrm{GHz})$ umożliwi 2-, 3-krotny wzrost szybkość transmisji danych $(<5 \mathrm{Mb} / \mathrm{s})$, co wydaje się być jednak niewystarczające przy wymaganej dwukierunkowej transmisji danych dla załogowej misji na Marsa $(100 \mathrm{Mb} / \mathrm{s})$. 
Tabela. 1. Przykładowa lokalizacja stacji kontroli systemu nawigacyjnego Marsa

Table 1 . The exemplary location of control station of marc navigational system

\begin{tabular}{|c|c|c|}
\hline Stacja kontroli & Szerokość areograficzna $\left({ }^{\circ}\right)$ & Długość areograficzna $\left({ }^{\circ}\right)$ \\
\hline NetLander $1^{22}$ & $27,0 \mathrm{~N}$ & $130,0 \mathrm{~W}$ \\
\hline NetLander 2 & $12,5 \mathrm{~S}$ & $160,0 \mathrm{~W}$ \\
\hline NetLander 3 & $35,0 \mathrm{~N}$ & $70,0 \mathrm{~W}$ \\
\hline NetLander 4 & $32,5 \mathrm{~S}$ & $85,0 \mathrm{E}$ \\
\hline MER Spirit & $14,57 \mathrm{~S}$ & $175,5 \mathrm{E}$ \\
\hline MER Opportuity & $1,95 \mathrm{~S}$ & $5,5 \mathrm{~W}$ \\
\hline Mars Polar Lander & $76,0 \mathrm{~S}$ & $175,0 \mathrm{E}$ \\
\hline Phoenix Mars Lander & $67,5 \mathrm{~N}$ & $120,0 \mathrm{~W}$ \\
\hline
\end{tabular}

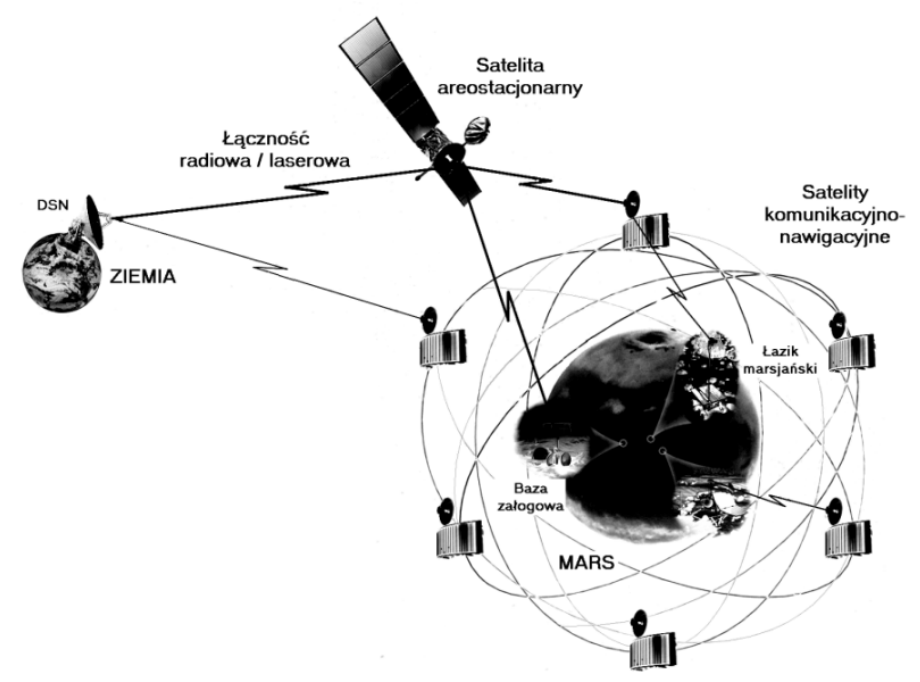

Rys. 7. Satelitarny system nawigacji i łaczności (transmisji danych) dla Marsa $^{23}$

Fig. 7. Satellite system of navigation and communication (data transmission) for Mars

Wzrost częstotliwości transmisji danych napotyka barierę technologiczną, wzrost rozmiarów sondy międzyplanetarnej (antena, źródła zasilania) - barierę

${ }^{22}$ NetLander - „misja zawieszona” (planowana w 2009 r.), wspólna misja CNES (Francuska Agencja Kosmiczna) i ESA (Europejska Agencja Kosmiczna), wysłania na Marsa orbitera i czterech lądowników - lądowanie w czterech różnych miejscach na Marsie.

${ }^{23}$ Satelita aerostacjonarny - sztuczny satelita Marsa znajdujący się na orbicie aerostacjonarnej - odpowiednik ziemskiej orbity geostacjonarnej dla Marsa „Areo” od imienia greckiego boga wojny Aresa (rzymski odpowiednik to Mars); wysokość orbity aerostacjonarnej $H=17033 \mathrm{~km}$ nad równikiem Marsa. 
„pojemności” rakiet nośnych (tab. 2.). Jedynym wyjściem wydaje się być wykorzystanie transmisji optycznej - jednokierunkowego (Mars - Ziemia) łącza laserowego, co spowoduje wzrost częstotliwości pracy $(\approx 300 \mathrm{GHz})$ przy jednoczesnym wzroście szybkości transmisji danych $(\leq 100 \mathrm{Mb} / \mathrm{s})$. Konieczność zapewnienia stałej (bez przerw) łączności z Ziemią wymaga lokalizacji sondy międzyplanetarnej $\mathrm{w}$ przestrzeni wokółmarsjańskiej, zapewniającej ciągły kontakt optyczny z Ziemią [8]. Satelity systemu nawigacyjnego krążące na teoretycznej wysokości $h_{S M}=509 \mathrm{~km}$ znajdują się w cieniu Marsa przez ok. 33\% (40,3 min) czasu obiegu planety; przerwa w łączności z Ziemią, system łączności (transmisji danych) dla Marsa powinien składać się z (rys. 7.):

- satelit niskoorbitalnych $\left(h_{S}=509 \mathrm{~km}\right)$ - satelity nawigacyjne zapewniające dodatkowo możliwość transmisji danych w skali całej planety,

- satelit wysokoorbitalnych - satelity komunikacyjne „pośredniczące” w łączności pomiędzy satelitami niskoorbitalnymi a Ziemią.

Satelity komunikacyjne (wysokoorbitalne) powinny znajdować się w przestrzeni wokółmarsjańskiej zapewniającej ciągły kontakt optyczny z Ziemią, co jest możliwe dla:

- dwóch satelitów komunikacyjnych znajdujących się w dwóch punktach Lagrange' ${ }^{24}$; położenie takie zapewnia ok. $99,8 \%$ „widzialności” powierzchni Marsa przez satelity, jednakże znaczna odległość punktów od powierzchni planety (ok. $1 \mathrm{mln} \mathrm{km}$ ),,pogarsza” warunki łączności Mars $\leftrightarrow$ satelita komunikacyjny; zasadniczym problemem jest stabilizacja położenia satelitów w punktach Lagrange'a $L_{1}-L_{2}$; łączność radiowa / laserowa z Ziemią,

- trzech satelitów komunikacyjnych rozmieszczonych co $120^{\circ}$ na orbicie areostacjonatnej $\left(h_{A S O}=17033 \mathrm{~km}\right)$, zapewniających ,widzialność” prawie 100\% powierzchni Marsa (ograniczona widzialność rejonów wokółbiegunowych).

Dla sztucznego satelity krążącego po kołowej orbicie areostacjonarnej ASO

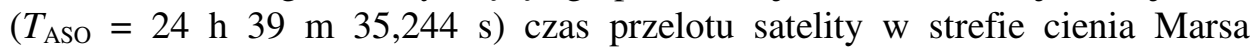
$T=4726,2 \mathrm{~s}$ ( 1 h $18 \mathrm{~min} \mathrm{46,2}$ s): 94,7\% - strefa oświetlona, 5,3\% - strefa cienia (okres równonocy wiosennej / jesiennej). Zastosowanie trzech satelitów rozmieszczonych symetrycznie na orbicie areostacjonarnej pozwala na realizację „ciągłej” łączności Mars - Ziemia - Mars (rys. 8.) [16]. Podczas laserowej transmisji jednokierunkowej Mars - Ziemia zastosowanie trzech zespołów odbiorczych na ziemskiej orbicie geostacjonarnej (co $120^{\circ}$ ) zapewni ciągłość transmisji przy ograniczeniu tłumienia wiązki laserowej w atmosferze Ziemi. Szacuje się, że dla zapewnienia ciągłości połączenia (brak „zrywania” wiązki

${ }^{24}$ Punkt libracyjny (punkt libracji, punkt Lagrange’a) - miejsce w przestrzeni w układzie dwóch ciał powiązanych grawitacją, w którym ciało o pomijalnej masie może pozostawać w spoczynku względem ciał układu. Dla układu trzech ciał (np. Słońce, Mars, satelita) występuje pięć takich punktów, $L_{1} \div L_{5}$. 
laserowej) położenie przestrzenne zespołów nadawczych i odbiorczych powinno być stabilizowane z dokładnością rzędu 4 mrad.

Tabela. 2. Porównanie parametrów transmisji danych przez orbitery Marsa

Table 2. Comparison of data transmission parameters by Mars orbiter

\begin{tabular}{|c|c|c|c|c|c|}
\hline \multirow{2}{*}{$\begin{array}{c}\text { Parametry } \\
\text { transmisji }\end{array}$} & \multicolumn{6}{|c|}{$\begin{array}{c}\text { Mars } \\
\text { Global } \\
\text { Surveyor }\end{array}$} & $\begin{array}{c}\text { Mars } \\
\text { Odyssey }\end{array}$ & $\begin{array}{c}\text { Mars } \\
\text { Express }\end{array}$ & $\begin{array}{c}\text { Mars } \\
\text { Reconnaissance } \\
\text { Orbiter }\end{array}$ & $\begin{array}{c}\text { Mars } \\
\text { Telecommunications } \\
\text { Orbiter }\end{array}$ \\
\hline Data startu & 1996 & 2001 & 2003 & 2005 & $?$ \\
\hline Czas pracy & 10 lat & 6 lat & 6 lat & 10 lat & 10 lat \\
\hline $\begin{array}{c}\text { Moc źródeł } \\
\text { zasilania }\end{array}$ & $0,98 \mathrm{~kW}$ & $0,75 \mathrm{~kW}$ & $0,5 \mathrm{~kW}$ & $2 \mathrm{~kW}$ & $1 \mathrm{~kW}$ \\
\hline $\begin{array}{c}\text { Średnica } \\
\text { anteny [m] }\end{array}$ & 1,5 & 1,5 & 1,6 & 3 & $3 \mathrm{Ka} / 0,3$ laser \\
\hline Pasmo & $X$ & $X$ & $S / X$ & $X / \mathrm{Ka}$ & $X / \mathrm{Ka} /$ laser \\
\hline $\begin{array}{c}\text { Szybkość } \\
\text { transmisji }\end{array}$ & $\begin{array}{c}25 \div 85 \\
\mathrm{~kb} / \mathrm{s}\end{array}$ & $\begin{array}{c}30 \div 124 \\
\mathrm{~kb} / \mathrm{s}\end{array}$ & $\begin{array}{c}28 \div 182 \\
\mathrm{~kb} / \mathrm{s}\end{array}$ & $500 \div 3500 \mathrm{~kb} / \mathrm{s}$ & $\begin{array}{c}10000 \div 30000 \\
\mathrm{~kb} / \mathrm{s}-\text { laser }\end{array}$ \\
\hline Technologia & radio & $\mathrm{radio}$ & $\mathrm{radio}$ & radio & radio / laser \\
\hline
\end{tabular}

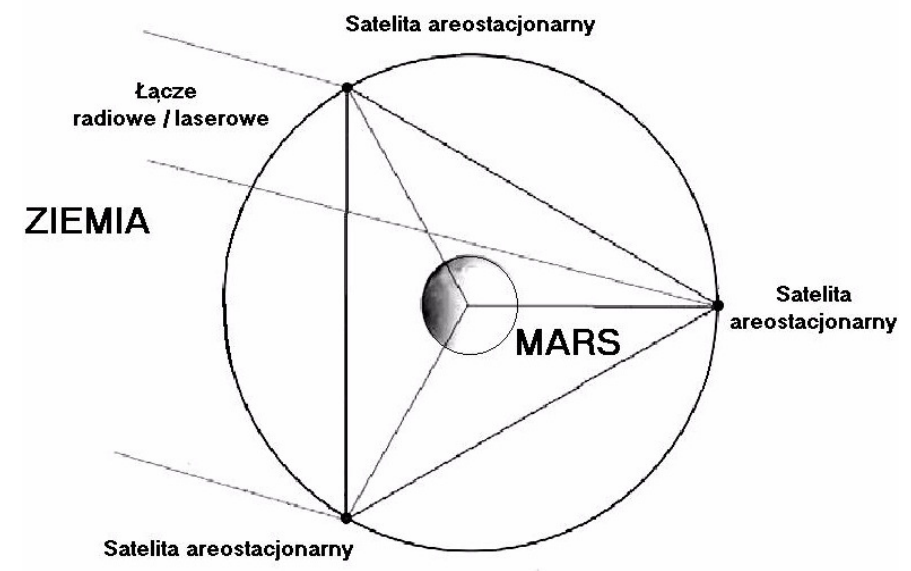

Rys. 8. Przykładowe rozmieszczenie satelitów areostacjonarnych na orbicie areostacjonarnej Marsa

Fig. 8. The exemplary arrangement of areostationary satellite on areostationary orbit of Mars

${ }^{25}$ Mars Telecommunications Orbiter - bezzałogowa sonda kosmiczna NASA, która miała zostać wystrzelona w kierunku Marsa we wrześniu 2009 r. Sonda miała być używana do przekazywania pakietów danych na Ziemię (hub) z różnych lądowników znajdujących się na Marsie i sond krążących po jego orbicie przez co najmniej 10 lat za pośrednictwem łącza laserowego (Laser InfraRed, $\lambda=1,06 \mu \mathrm{m}, P=5 \mathrm{~W}+$ teleskop $\emptyset=0,3 \mathrm{~m}$; powyżej $2 \mathrm{~GB}$ danych dziennie). Odbiór na Ziemi - teleskop $\varnothing=5 \mathrm{~m}$. 


\section{Podsumowanie}

W pracy dokonano analizy współczesnych systemów nawigacji i łączności z sondami międzyplanetarnymi w obrębie Układu Słonecznego, ze szczególnym uwzględnieniem misji marsjańskich. Na podstawie obcnego poziomu eksploracji Marsa został opracowany projekt koncepcyjny systemu nawigacji i łączności (transmisji danych) dla obiektów znajdujących się na powierzchni Marsa i w przestrzeni wokółmarsjańskiej. W pracy przedstawiono koncepcję wykorzystania konstelacji sześciu niskoorbitalnych sztucznych satelitów nawigacyjnych i trzech stacjonarnych satelitów komunikacyjnych, umożliwiających realizację ciągłej nawigacji i dwukierunkowej transmisji danych dla obiektów znajdujących się zarówno na powierzchni Marsa, jak i w bliskiej przestrzeni kosmicznej za pośrednictwem łączy radiowych i optycznych (laser).

\section{Literatura}

[1] Chrzczonowski A. i in.: Projekt koncepcyjny marsjańskiego samolotu zasilanego ogniwami fotoelektrycznymi. Mechanika w lotnictwie ML-XV, 2012.

[2] Godwin R.: Mars - historia podboju kosmosu. Prószyński Media, Warszawa 2011.

[3] Sanctis M. i in.: Flower constellation of Orbiters for Martian communication. IEEE, 2007.

[4] Lauf J. i in.: Clock and iming in the NASA Deep Space Network. IEEE, 2005.

[5] Melbourne W.: Navigation between the Planets. Scientific American, June 1976.

[6] Bem D.J.: Systemy telekomunikacyjne, cz. III. Politechnika Wrocławska, Wrocław 1991.

[7] O'Keefe K.: Simulation and evaluation of the performance of the proposed Mars Network Constellation. UCGE Reports No. 20191. University of Calgary, Calgary 2004.

[8] Palimerini G.: Design fo a Mars Relay and navigation satellite network. IEEE, 2003.

[9] Larson J. i in.: Space mission analysis and design. Wiley, Warszawa 1999.

[10] Tingting H.: A preliminary designation for constellation distribution for Mars GNSS. IEEE, 2009.

[11] Ely T. i in.: Mars network constellation design drivers and strategies. AAs, 99-301.

[12] Januszewski J.: Systemy satelitarne GPS. Galileo i inne. PWN, Warszawa 2010.

[13] Pawelec J.: Radiosterowanie i łączność kosmiczna. WKił, Warszawa 1991.

[14] Ley W.: Handbook of space technology. Wiley, Warszawa 2008.

[15] Zubrin R. i in.: Czas Marsa. Prószyński i S-ka, Warszawa 1997.

[16] Jaroszewicz A. i in.: Wykorzystanie energii słonecznej w technice kosmicznej. Aktualne kierunki rozwoju energetyki. Politechnika Wrocławska, Wrocław 2012. 


\title{
CONCEPTUAL PROJECT OF GLOBAL NAVIGATION SYS-
} TEM FOR MARS

\begin{abstract}
Mars has become the object of an unprecedented race of many countries in the exploration of the planet, which is to become the crowning achievement of landing humans on the surface of the Red Planet. Manned mission to Mars will require the construction of a global navigation system of the planet and ensure continuous broadband data transmission to Earth. The contemporary navigation of interplanetary probes in outer space is a complex, time-consuming and expensive process required to operate a complex ground-based infrastructure. The navigation process is fully nonautonomous and the probe, using on-board equipment, can not find its spatial position in taken reference system. The article presents the conceptual project of Doppler global navigational system for Mars planet allowing for finding position of the object at the planet's surface and in space at the time not exceeding two hours and the communication system assuring mutual communication between probes/lander and data retransmission from Mars to Earth.
\end{abstract}

Keywords: Mars, navigation system, data transmission

DOI:10.7862/rm.2013.25

Otrzymano/received: 15.09 .2013

Zaakceptowano/accepted: 22.10 .2013 